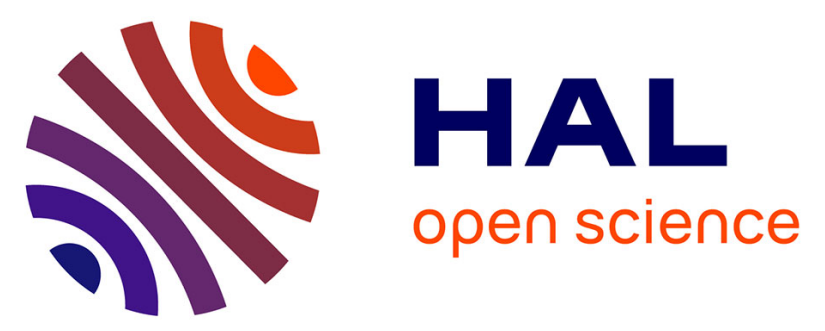

\title{
Response to canopy opening does not act as a filter to Fagus sylvatica and Acer sp. advance regeneration in a mixed temperate forest
}

Blandine Caquet, Pierre Montpied, Erwin Dreyer, Daniel Epron, Catherine

Collet

\section{To cite this version:}

Blandine Caquet, Pierre Montpied, Erwin Dreyer, Daniel Epron, Catherine Collet. Response to canopy opening does not act as a filter to Fagus sylvatica and Acer sp. advance regeneration in a mixed temperate forest. Annals of Forest Science, 2010, 67 (1), pp.1-11. 10.1051/forest/2009086 . hal-00883559

\section{HAL Id: hal-00883559 \\ https://hal.science/hal-00883559}

Submitted on 1 Jan 2010

HAL is a multi-disciplinary open access archive for the deposit and dissemination of scientific research documents, whether they are published or not. The documents may come from teaching and research institutions in France or abroad, or from public or private research centers.
L'archive ouverte pluridisciplinaire HAL, est destinée au dépôt et à la diffusion de documents scientifiques de niveau recherche, publiés ou non, émanant des établissements d'enseignement et de recherche français ou étrangers, des laboratoires publics ou privés. 


\title{
Response to canopy opening does not act as a filter to Fagus sylvatica and Acer sp. advance regeneration in a mixed temperate forest
}

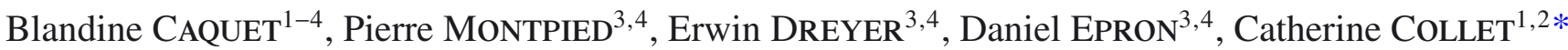 \\ ${ }^{1}$ INRA, UMR1092 LERFoB, 54280 Champenoux, France \\ ${ }^{2}$ AgroParisTech, UMR1092 LERFoB, 54280 Champenoux, France \\ ${ }^{3}$ INRA, UMR 1137 Écologie et Écophysiologie Forestières, 54280 Champenoux, France \\ ${ }^{4}$ Nancy-Université, UMR 1137 Écologie et Écophysiologie Forestiéres, 54500 Vandoeuvre-les-Nancy, France
}

Keywords:

canopy gap /

competition /

light acclimation /

shade tolerance /

Acer pseudoplatanus /

Acer campestre /

Acer platanoides

Mots-clés :

trouée forestière /

acclimatation à la lumière /

tolérance à l'ombre /

Acer pseudoplatanus /

Acer campestre /

Acer platanoides
(Received 8 March 2009; accepted 17 June 2009)

\begin{abstract}
- In mixed-species forest stands, large losses in tree species diversity often occur during the regeneration phase. In a former coppice-with-standards, we investigated whether the limiting stage in the recruitment process of advance regeneration is the immediate seedling response to canopy release. Experimental canopy gaps were opened and the survival and growth of advance seedlings (Fagus sylvatica, Acer pseudoplatanus, Acer campestre, Acer platanoides) growing in the gaps or under closed canopy were monitored for three years.

- All species responded positively and rapidly to canopy release. Survival was not affected by gap opening. Diameter increment after gap opening was similar across species, and height increment was greater for Acer platanoides and for Acer pseudoplatanus. Post-release diameter and height growth were mainly determined by pre-release seedling size. Competition from neighbouring seedlings did not affect growth in the three years following canopy opening.

- In the recruitment process of F. sylvatica and Acer sp. advance regeneration, the recovery from canopy release did not appear as a limiting step that would filter against some species. Pre-release size was the main factor accounting for post-release growth and is probably a major determinant of long-term seedling dominance.
\end{abstract}

Résumé - La réponse à l'ouverture du couvert ne filtre pas les semis préexistants de Fagus sylvatica et Acer sp. dans une forêt mélangée tempérée.

- Dans les peuplements mélangés, une forte réduction de la diversité spécifique a lieu au cours de la phase de régénération. Nous avons examiné dans un ancien taillis-sous-futaie dans quelle mesure la réponse immédiate des semis à l'ouverture du couvert adulte pouvait limiter le recrutement de semis préexistants. Des trouées ont été ouvertes dans le couvert, et la survie et la croissance de semis préexistants (Fagus sylvatica, Acer pseudoplatanus, Acer campestre, Acer platanoides), situés dans les trouées ou bien sous couvert fermé, ont été suivies pendant trois années.

- Les quatre espèces ont répondu positivement et rapidement à l'ouverture du couvert. La survie n'a pas été affectée par l'ouverture. Pour les semis dans les trouées, l'accroissement en diamètre était similaire pour les quatre espèces et l'accroissement en hauteur était plus important pour Acer platanoides et Acer pseudoplatanus. La croissance en hauteur et en diamètre après ouverture étaient principalement déterminées par les dimensions des semis avant ouverture. La compétition exercée par les semis voisins n'a pas affecté significativement la croissance dans les trois années qui ont suivi l'ouverture.

- La période d'acclimatation des semis aux nouvelles conditions après ouverture de la canopée n'est pas apparue comme un stade limitant le recrutement des semis préexistants de Fagus sylvatica, Acer sp., ni comme un filtre vis-à-vis de l'une des quatre espèces. Les dimensions initiales des semis constituaient le facteur principal expliquant la croissance après ouverture, et probablement un facteur explicatif important pour la dominance future des semis vis-à-vis de leurs voisins.

\footnotetext{
* Corresponding author: collet@nancy.inra.fr
} 


\section{INTRODUCTION}

Paradigms in forest management practice have shifted in recent decades towards the development of silvicultural scenarios that aim at preserving or promoting species diversity during the regeneration process. In such scenarios, the main difficulty is usually to maintain existing high species diversity throughout the regeneration phase (Puettmann and Ammer, 2007). As pointed out by Peet and Christensen (1987), most trees die during the early stages of forest development. In most forests, the regeneration phase is characterised by extensive seedling establishment and high mortality rates, and the sharpest decrease in tree number and species diversity occurs during this phase (Clark et al., 1999; Nakashizuka, 2001).

Among the different theories proposed to explain species coexistence (Silvertown, 2004), two are particularly meaningful for the design of management practices aimed at promoting species diversity during regeneration:

(1) Niche differentiation along spatial gradients of resource availability, long recognised as a potential mechanism for the coexistence of species in plant communities (Grubb, 1977), has been widely implemented by forest managers. Silvicultural scenarios have been developed in many types of forests where large gradients of resource availability are created over short spatial scales by opening canopy gaps of different sizes and shapes. Tree species with different requirements may regenerate and establish along these gradients (Dalling et al., 1998; Pearson et al., 2003).

(2) Storage effect is a mechanism involved in the temporal niche differentiation process. It occurs when tree species have the ability to recover from long periods of low recruitment after having been "stored" in the seed bank or in the population of established recruits that survive over the long term (Chesson et al., 2001). Although many theoretical (Kelly and Bowler, 2002; Takenaka, 2006) and field studies (Bourgeois et al., 2004; Parish and Antos, 2005) have shown that storage effect may enhance species diversity or may ensure successful regeneration of some tree species, only a few silvicultural scenarios have been developed based on the use of persistent seedlings (also known as advance seedlings) to promote species diversity, at least in Europe.

Designing silvicultural scenarios that use advance regeneration requires a clear understanding of the factors affecting the successive steps of the recruitment process of advance regeneration. Three steps and their associated processes are usually considered (Parish and Antos, 2005): (i) survival of the persistent seedling bank in the pre-harvest forest; (ii) immediate response of the advance seedlings to canopy opening; and (iii) long-term survival and growth in the openings, in competition with other seedlings. The relative importance of each of the three steps in limiting the overall recruitment may vary with site conditions, stand composition and structure, and climate (Silvertown, 2004). It is important to identify the most limiting step with the greatest consequence for the final outcome, and the main factors that filter against seedling survival and growth during these limiting steps. Adequate silvi- cultural treatments designed to overcome these limitations and to favour the desired tree species may then be established.

The general objective of the present study was to identify the limiting steps in the recruitment of advance regeneration in a former coppice-with-standards. Coppice-with-standards are typical formations of western Europe, usually characterised by high species diversity in the canopy and in the understorey (Decocq et al., 2005; Gonzalez et al., 2008). In a former coppice-with-standards in north-eastern France, Collet et al. (2008) observed that despite a large tree species diversity (up to 12 species) in the overstorey, the new tree population at the end of the regeneration phase was strictly dominated by two species (Fagus sylvatica L. and Acer pseudoplatanus L.), and that creating canopy gaps of different sizes did not result in a more diverse regeneration. In these forests, dominant $F$. sylvatica and $A$. pseudoplatanus seedlings mainly originate from advance regeneration that persisted under the closed canopy in the pre-harvest stand. Two additional species, Acer campestre L. and A. platanoides L., are present in high numbers in the persistent seedling bank, but are totally absent at the end of the regeneration phase. Two features may possibly filter against the two latter species: (1) an inability to positively and rapidly respond to canopy opening; and (2) an inability to compete with $F$. sylvatica and A. pseudoplatanus after canopy opening. Additionally, these two features may be modulated by the social status and the size of individuals within the persistent seedling bank (Grogan et al., 2005; Krasowski and Wang, 2003).

Our study was designed to examine the immediate response of advance $F$. sylvatica, A. pseudoplatanus, A. campestre and A. platanoides to canopy release. We opened experimental canopy gaps and monitored the survival and growth of advance seedlings in gaps or under a closed canopy for four years. We analysed the combined effects of competition from neighbours, light availability and initial size on seedling survival and growth. Our specific objectives were: (1) to assess whether the limiting stage in the recruitment process of $A$. campestre and A. platanoides is the recovery from gap creation, i.e., whether the absence of seedlings at the end of the regeneration phase may be ascribed to a negative immediate response (mortality or lack of rapid post-release growth) to canopy opening; (2) to assess the extent to which the immediate response of individual seedlings was related to their initial size; (3) to discuss implications for silvicultural scenarios aimed at promoting species diversity in former coppice-with-standards.

\section{MATERIAL AND METHODS}

\subsection{Study site}

The study site was located in the Graoully forest $\left(49^{\circ} 04^{\prime} 40^{\prime \prime} \mathrm{N}, 6^{\circ} 01^{\prime} 02^{\prime \prime} \mathrm{E}\right)$, close to Metz in Lorraine, north-eastern France, on a limestone plateau at approximately $300 \mathrm{~m}$ asl. Soil characteristics (a 40- to 60-cm-deep calcisol) were homogeneous over the whole site (Piboule et al., 2005). Annual average temperature and precipitation were $10.1{ }^{\circ} \mathrm{C}$ 
Table I. Characteristics of the four regeneration patches under canopy $(C)$ and in gaps $(G)$ in the two plots, assessed during spring and summer 2005: range of relative irradiance values (RI), patch size, average seedling density, seedling height and diameter (mean \pm SE) for each species.

\begin{tabular}{|c|c|c|c|c|}
\hline & \multicolumn{2}{|c|}{ Plot 1} & \multicolumn{2}{|c|}{ Plot 2} \\
\hline & $\mathrm{C}$ & $\mathrm{G}$ & $\mathrm{C}$ & G \\
\hline RI (min-max \%) & $4.3-6.8$ & $24.0-36.8$ & $3.0-7.2$ & $35.9-49.9$ \\
\hline Patch size $\left(\mathrm{m}^{2}\right)$ & 58.9 & 66.6 & 65.9 & 79.9 \\
\hline Average seedling density $\left(\mathrm{m}^{-2}\right)$ & 4.7 & 6.9 & 12.5 & 18.9 \\
\hline \multicolumn{5}{|l|}{ Diameter (mm) } \\
\hline A. pseudoplatanus & $2.65 \pm 1.55$ & $4.46 \pm 1.58$ & $2.86 \pm 1.37$ & $2.68 \pm 1.30$ \\
\hline A. campestre & $1.6 \pm 0.93$ & $3.21 \pm 1.18$ & $1.84 \pm 0.94$ & $1.62 \pm 0.65$ \\
\hline A. platanoides & $2.16 \pm 1.39$ & $4.41 \pm 1.57$ & $2.00 \pm 0.93$ & $2.16 \pm 1.20$ \\
\hline F. sylvatica & $4.86 \pm 2.32$ & $5.57 \pm 2.36$ & $5.89 \pm 3.97$ & $4.86 \pm 2.59$ \\
\hline \multicolumn{5}{|l|}{ Height $(\mathrm{cm})$} \\
\hline A. pseudoplatanus & $43.3 \pm 19.0$ & $44.7 \pm 21.9$ & $21.5 \pm 10.5$ & $18.5 \pm 11.2$ \\
\hline A. campestre & $17.6 \pm 8.2$ & $26.8 \pm 13.9$ & $13.1 \pm 6.7$ & $11.3 \pm 4.7$ \\
\hline A. platanoides & $26.7 \pm 17.7$ & 34. \pm 17.6 & $13.2 \pm 7.2$ & $13.5 \pm 8.1$ \\
\hline F. sylvatica & $66.4 \pm 32.0$ & $71.2 \pm 35.3$ & $61.7 \pm 40.9$ & $51.4 \pm 26.8$ \\
\hline
\end{tabular}

and $745 \mathrm{~mm}$, respectively. The stand had been managed under a coppice-with-standards regime until the beginning of the 1960s, when the conversion into high forest began. As of that date, harvesting of the coppice stopped and only a few sanitary thinnings were performed. In 2003, the stand was dominated by $F$. sylvatica L. and Carpinus betulus L., on a basal area basis. Stand basal area was $25.6 \mathrm{~m}^{2} \mathrm{ha}^{-1}$ and density was 550 stems ha $^{-1}$. Dominant trees (former standards) were mainly F. sylvatica, Quercus petraea (Matt.) Liebl., Q. robur L., A. pseudoplatanus, A. platanoides, Fraxinus excelsior L., and some scattered Sorbus torminalis (L.) Crantz.. Coppice was mainly composed of C. betulus, A. campestre, Tilia cordata Mill., T. platyphyllos Scop. and S. aria (L.) Crantz.. An abundant natural regeneration was present below the canopy in most of the stand.

In June 2004, two distinct plots, $300 \mathrm{~m}$ apart, containing a mixed advance regeneration of $F$. sylvatica, $A$. pseudoplatanus, A. campestre and A. platanoides growing in an intimate mixture, were selected within the site. Each plot was split into two subplots, $50 \mathrm{~m}$ apart. The plots and subplots were selected in order to ensure similar pairs of subplots in terms of average species composition, density and seedling height. A felling was carried out during January 2005 above one subplot of each plot, resulting in increased irradiance (gap treatment: G), while the full canopy was maintained in the other subplot (canopy treatment: C). In each of the four subplots (in gaps or under canopy), the boundaries of a regeneration patch with irregularly clumped seedlings were determined. Patch size, average seedling density, average seedling size and species composition in the selected patches are indicated in Table I. A total number of 225, 1830, 664 and 293 seedlings were selected for F. sylvatica, A. pseudoplatanus, A. campestre and A. platanoides, respectively. A companion study (Caquet, 2008) performed on $F$. sylvatica and A. pseudoplatanus in the same stand showed that small seedlings with a diameter of up to 3-4 mm were generally less than 10 years old. For larger seedlings (diameter $>4 \mathrm{~mm}$ ), age was more variable and ranged between 10 and $35 \mathrm{y}$. Similar information was not available for $A$. campestre and $A$. platanoides.
At the beginning of the experiment, a few other woody or herbaceous species were scattered in the selected patches and were manually removed in order to avoid any competition from other species. However, creeping Hedera helix L. was not removed to avoid seedling uprooting. Manual vegetation control was performed twice a year throughout the duration of the experiment to prevent the establishment of new seedlings or neighbouring vegetation. The plots were fenced to prevent browsing by deer.

\subsection{Measurements}

During March 2005, all seedlings in the studied plots were labelled and mapped. During March 2005 and December 2005, 2006 and 2007, the status (dead or alive), total height (stretched length) and basal diameter (5 $\mathrm{cm}$ above ground) were measured for each seedling.

In summer 2005, hemispherical photographs were taken with a digital camera (Coolpix 5000 with a FC-E8 fish-eye lens, Nikon Corporation, Tokyo, Japan) at a height of $1.50 \mathrm{~m}$ on a $2 \mathrm{~m} \times 2 \mathrm{~m}$ grid in each regeneration patch. Photographs were manually thresholded to black and white, and relative irradiance (RI) was calculated for each photograph using HemIMAGE software (Brunner, 1998). The RI above each seedling was then calculated by linear interpolation between the RI measurement points, located on the grid. The range of RI values calculated in each regeneration patch in summer 2005 is reported in Table I.

\subsection{Analytical approach}

The general objective was to analyse the combined effects of competition from neighbours, light availability and initial seedling size on seedling height and diameter increment for each of the four species, using ordinary least-square regression models. All data treatments and statistical analyses were performed with $\mathrm{R}$ version 2.6.1 software ( $\mathrm{R}$ Development Core Team, 2007). 


\subsubsection{Selection of independent variables}

The degree of competition induced by neighbouring tree seedlings on each seedling was quantified using competition indices (CI). We compared different CIs that accounted for the number, the size and/or the distance of neighbouring seedlings. In a preliminary analysis, we also tested the effect of neighbour species identity on the growth of the target seedlings. No statistically significant effect of neighbour species identity was found and neighbour species was therefore not introduced into the selected CIs. A series of circular neighbourhoods centred on the target seedling with radii ranging from 10 to $200 \mathrm{~cm}$ was tested.

All CIs were of the following general form:

$$
C I_{i r}=\sum_{j} \frac{\text { size }_{j}}{\text { weigh }_{j i}}
$$

where $C I_{i, r}$ is the $C I$ around target seedling $i$ taking all seedlings within a neighbourhood with radius $r=$ $\{10,20,30, \ldots, 200 \mathrm{~cm}\}$ into account, size ${ }_{j}$ is the size of neighbouring seedling $j$ (size ${ }_{j}=$ height $_{j}$, or size ${ }_{j}=\mathrm{BA}_{j}$, where height ${ }_{j}$ and $\mathrm{BA}_{j}$ are the height and basal area of seedling $j$, respectively, or $\operatorname{size}_{j}=1$ ), and weigh ${ }_{j}$ is a weighing coefficient for seedling $j$ (weight (wi $_{j i}=$ dist $_{j i}$, where dist ${ }_{j i}$ is the distance between target seedling $i$ and neighbouring seedling $j$, or weight $_{j i}=\left(1-\text { dist }_{j i}\right)^{2}$, or weight $\left.j i=1\right)($ Collet and Chenost, 2006; Silander and Pacala, 1985).

The different $C I$ s calculated over the different neighbourhoods were compared. However, in the final analysis, the effects of CI on seedling growth were not statistically significant (see results). Therefore, for reasons of brevity, we have presented only the CI that performed the best, which was defined as the sum of the basal area of all neighbouring seedlings located in a 70-cm-radius circular neighbourhood centred on the target seedling (in the above equation: size $_{j}=\mathrm{BA}_{j}$ and weight $_{j i}=1$, with $r=70 \mathrm{~cm}$ ). Since this CI could not be calculated for target seedlings located at less than $70 \mathrm{~cm}$ from the plot boundary, only the seedlings located at more than $70 \mathrm{~cm}$ of the plot boundary were considered in models that included CI (2926 seedlings out of 3074 seedlings).

In a first analysis, the effects of relative irradiance on seedling height and diameter growth were modelled using alternative growth-irradiance functions, which expressed growth as: (i) a constant effect within each treatment; (ii) as a linear function of the interpolated $R I$ values above each seedling; or (iii) as a combination of a linear function of $R I$ above each seedling and a treatment effect. These different functions were introduced into models that expressed height or diameter growth as a function of competition, $R I$ and initial size, and then compared. The differences among the resulting models were small: pairwise model comparison indicated significant differences between models $(p-$ value $<0.05$ ) only for A. pseudoplatanus and A. platanoides (for both height and diameter growth) and the differences in adjusted- $r^{2}$ among the best and the worst of the three models was always less than 0.045 for all species (data not shown). Therefore, the simplest form expressing the effect of $R I$ as a constant effect within each treatment was selected in all subsequent models (treatment $=\mathrm{G}$ or $\mathrm{C}$ ).

Initial seedling size was introduced into the models in the form of stem diameter or height at the beginning of the growth period. At the beginning of the experiment (2005), no correlation was detected between the three independent variables (CI, treatment, initial size).

\subsubsection{Model development}

\section{Model development involved two steps.}

Step 1. Identifying the best set of independent variables to explain height and diameter increments over the three years, in a model form that could fit all four species. The choice of the best model form was based on:

(1) Comparison of different transformations (logarithm, square root) of both independent or dependent quantitative variables using distribution of residuals, constancy of variance and adjusted- $r^{2}$. Following this analysis, models including the logarithm of growth, the logarithm of initial size and untransformed values of CI were chosen. The models including the other transformations of variables are not presented.

(2) Comparison of full models that contained all independent variables (initial size, treatment and $\mathrm{CI}$ ) and their interactions to the highest order, and restricted models (containing only a subset of the independent variables), using ANOVAs to test the inclusion of the different independent variables.

Step 2. Using the selected model to analyse the effects of competition, treatment and initial size on height and on diameter growth, for each year and for each of the four species separately.

Some negative increment values were found as a result of height or diameter measurement errors or stem dieback. When fitting the models, these negative values were kept in order not to introduce any bias. When using log or square root transformations, a constant value ( $\mathrm{k}$, lower than the smallest negative value) was added to all individual increment values in order to allow calculation.

\section{RESULTS}

\subsection{Model selection}

Full models containing all independent variables (competition index-CI, initial size, relative irradiance treatment "Canopy-C" or "Gap-G") and their interactions were compared to models where one of the three independent variables was removed, for each species and for height and diameter increments over the three years. The ANOVAs showed that the 


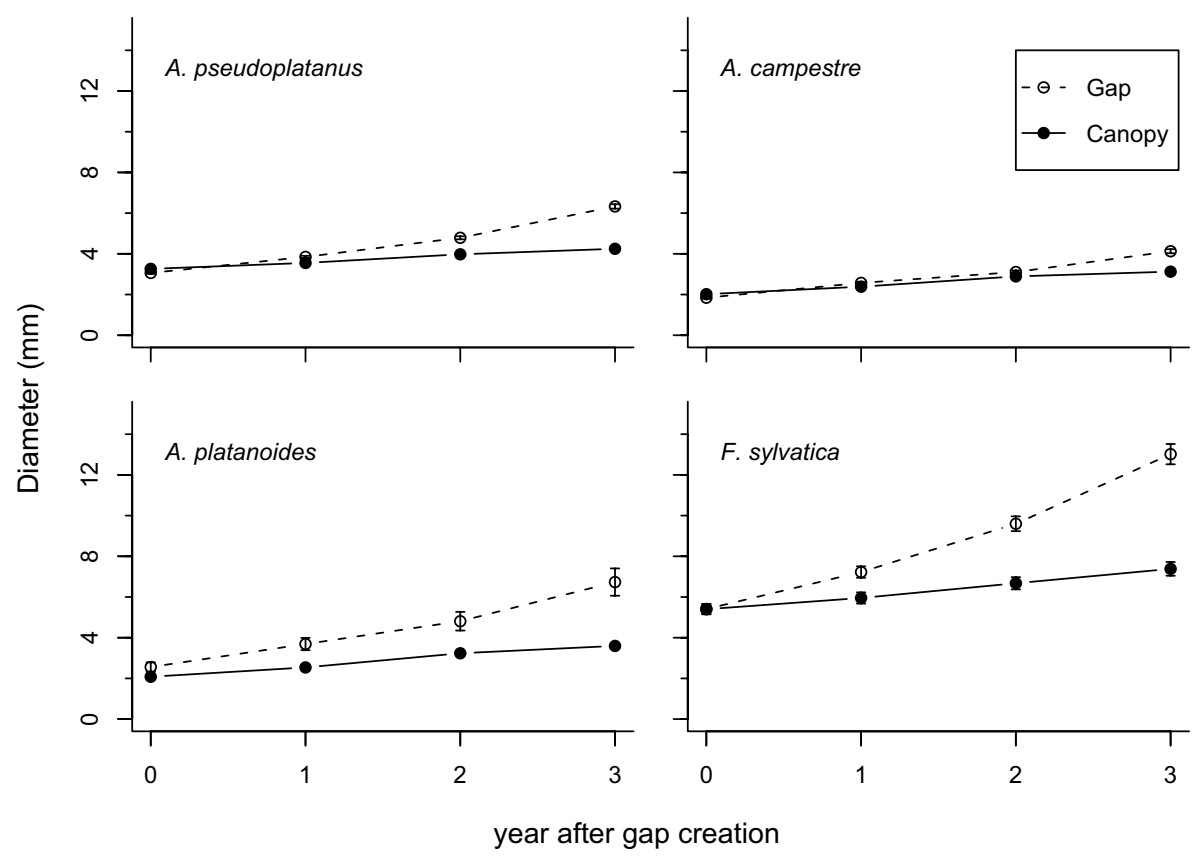

Figure 1. Basal diameter of canopy and gap seedlings of the four species (mean \pm SEM) as a function of year after gap opening.

effects of initial size and treatment were statistically significant in all models ( $p<0.001$ for all species). On the contrary, $\mathrm{CI}$ appeared to have a significant effect only for height increment of A. pseudoplatanus ( $p<0.01$ ). For all other species, its effect was never statistically significant $(p>0.05)$, indicating that at this stage, seedlings were probably too small to significantly affect their neighbours. The competition index was therefore removed from all subsequent models.

The model finally selected to compare the response of the four species to canopy opening was:

$$
\begin{aligned}
& \log (\text { growth }+k)= \\
& \log (\text { initial size })+\text { treat }+\log (\text { initial size }) \cdot \text { treat }
\end{aligned}
$$

where growth refers to individual seedling diameter or height increment over a given period, initial size to seedling diameter or height at the beginning of the growth period, treat to seedling treatment (treat $=0$ for seedlings in $\mathrm{G}$ and treat $=1$ for seedlings in C), and $k$ to a constant to avoid negative values of growth.

\subsection{Mortality, diameter and height growth}

Mortality over the three years of the experiment was 5, 9, 5 and $10 \%$ for F. sylvatica, A. pseudoplatanus, A. platanoides and $A$. campestre, respectively. For each of the four species, chi-square tests did not detect significant differences between $\mathrm{C}$ and $\mathrm{G}$, or among the three years.

At the beginning of the experiment, average diameter and height were similar in $\mathrm{C}$ and $\mathrm{G}$ for the four species. Irrespective of treatment, $F$. sylvatica seedlings were on average larger and taller, and A. campestre seedlings smaller than the other species (Tab. I). Three years after canopy opening, seedlings in the gaps displayed significantly greater diameter and height than those under canopy in all species $(p<0.001$, Figs. 1 and 2).

One year after gap opening, mean diameter was significantly larger in $\mathrm{G}$ than in $\mathrm{C}$ for all four species $(p<0.05)$. For A. platanoides, height growth response to canopy opening was immediate and mean total seedling height was significantly greater in $\mathrm{G}$ than in $\mathrm{C}$ the first year after gap creation $(p=0.002)$. For the three other species, height growth response to canopy opening showed a one-year time lag and significant differences appeared between the two treatments only two years after canopy opening ( $p<0.01$ for A. pseudoplatanus and A. campestre and $p<0.02$ for $F$. sylvatica). For all species, these differences increased later on.

Diameter growth models for F. sylvatica and A. pseudoplatanus generally had a greater predictive ability (adjusted- $r^{2}$ ) than height growth models (Tab. II). The opposite trend was observed with A. platanoides, and the higher predictability for height growth was attributed to a stronger effect of initial seedling size in treatment $\mathrm{G}$ for this species.

For the three Acer species, diameter and height increment increased with initial size in $\mathrm{G}$ and remained constant, irrespective of initial size in C (Figs. 3 and 4, Tab. II). For F. sylvatica, diameter growth increased with initial size, whereas height growth did not depend on initial size in either treatment.

Three years after gap opening, large differences occurred in average seedling diameter among the four species in $G$ (Fig. 1). However, most of the interspecific differences were absorbed by taking the initial size into account (Fig. 5). Similarly, in C, all species had similar diameter increments once initial size had been considered. A different pattern was observed for height increment in G. Three years after gap 


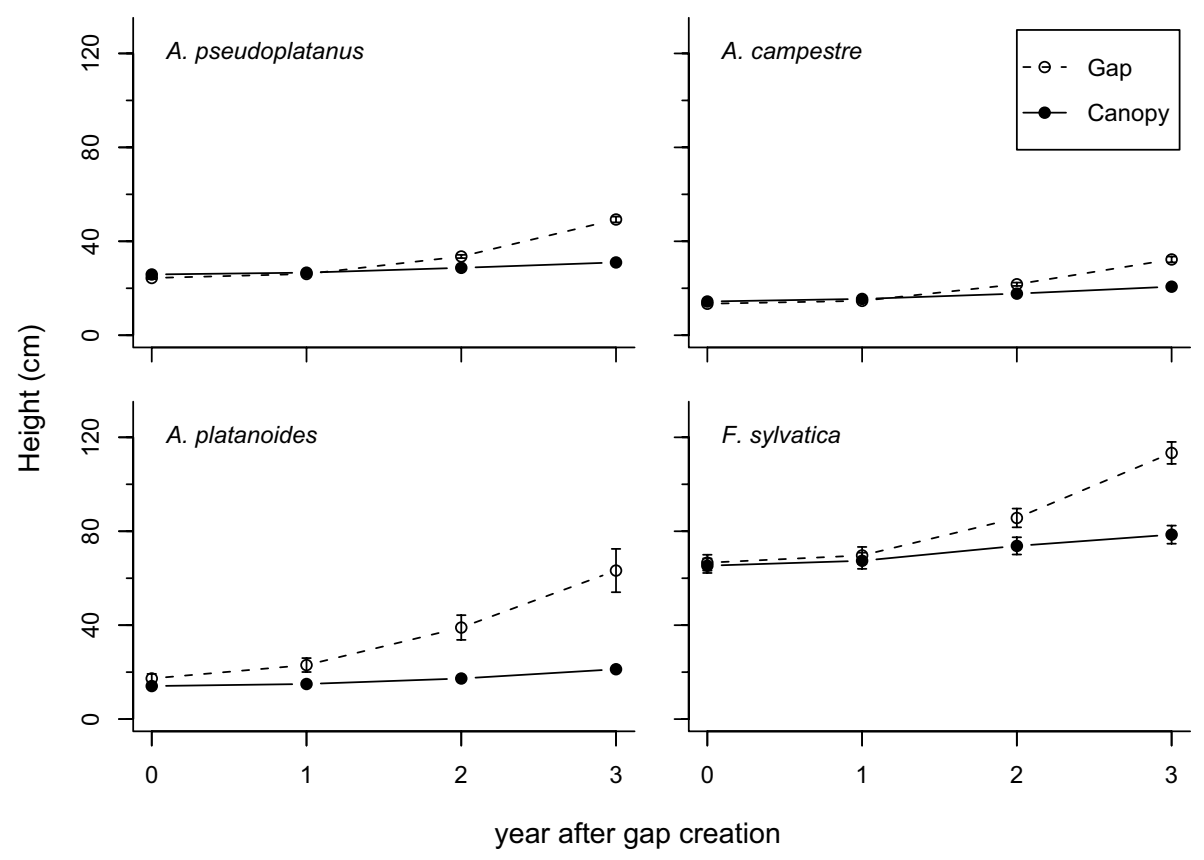

Figure 2. Height of canopy and gap seedlings of the four species (mean \pm SEM) as a function of year after gap opening.

creation, large differences in average seedling height also existed among the four species in G (Fig. 2). However, considering initial size did not remove all the differences in height in 2007 among the four species (Fig. 5). For initially small seedlings (initial height in $2004<30 \mathrm{~cm}$ ), height increment was similar for all species. However, for taller seedlings (initial height in $2004>30 \mathrm{~cm}$ ), A. platanoides seedlings showed a larger increment for a given initial height, A. pseudoplatanus had an intermediate height increment and $F$. sylvatica had the lowest increment. Very few A. campestre seedlings were initially taller than $30 \mathrm{~cm}$, precluding the comparison in this range of initial height for this species.

\section{DISCUSSION}

\subsection{Seedling response to canopy opening}

All four species displayed a rapid growth increase after canopy opening. As previously shown for F. sylvatica (Collet and Chenost, 2006) and other species (Aussenac, 2000; Kneeshaw et al., 2002), the response of F. sylvatica and the three Acer species to sudden canopy opening involved a rapid increase of diameter increment and a slightly delayed increase of height increment. In addition to the rapid growth response, seedling mortality was not significantly altered by gap creation, in contradiction with the few studies where post-release mortality of advance regeneration was recorded (Örlander and Karlsson, 2000; Parish and Antos, 2005). In the present study, the development of all non-tree vegetation was strictly controlled throughout the duration of the experiment, which may explain some of the differences observed with other studies conducted under natural conditions. Herbaceous vegetation usually shows a rapid establishment and growth immediately after canopy release and, if not controlled, may strongly reduce seedling growth and survival (Balandier et al., 2006).

Differences among species in the magnitude of response to canopy opening have been repeatedly reported (Kneeshaw et al., 2002; Wright et al., 2000). Our first objective was therefore to test whether differences in the response to gap opening occurred among Fagus and the three Acer species, which could filter against A. platanoides and A. campestre and explain their absence at later stages of the regeneration phase. The four species displayed similar patterns of diameter growth after canopy opening. On the contrary, height growth dynamics differed among species and when comparing height growth for a given initial height, the species were ordered as follows (from largest to smallest increment): A. platanoides, A. pseudoplatanus, and $F$. sylvatica. Due to smaller size, it was more difficult to compare A. campestre to the other species, but over the size range common to all species, no evidence of a poorer height growth response could be observed for $A$. campestre. The ability to survive and to recover active growth immediately after canopy opening was therefore not a process that filtered against A. platanoides and A. campestre.

Within each of the four species, growth after canopy opening was mainly controlled by pre-release seedling size. Before canopy opening, F. sylvatica seedlings were taller and displayed larger basal diameter than Acer seedlings and, among the Acer species, A. pseudoplatanus seedlings were the largest and A. campestre the smallest. A survey of the persistent seedling bank under closed canopy performed at stand scale (Collet et al., 2008) showed an identical ranking of the four species when comparing seedling height and diameter. This ranking is consistent with the composition of the regeneration at the end of the regeneration phase, which is strictly 
Table II. Predicting individual seedling height and diameter growth for the four species and for four growth periods: model predictive ability $\left(\operatorname{adj}-R^{2}\right)$ and coefficient estimates.

\begin{tabular}{|c|c|c|c|c|c|c|c|c|c|}
\hline \multirow[b]{2}{*}{ Increment } & \multirow[b]{2}{*}{ Species } & \multirow[b]{2}{*}{$\begin{array}{c}\text { Growth } \\
\text { period }\end{array}$} & \multirow[b]{2}{*}{$k$ value } & \multirow[b]{2}{*}{$n$} & \multirow[b]{2}{*}{$\mathrm{Adj}-R^{2}$} & \multicolumn{3}{|c|}{ Model coefficients } & \multirow[b]{2}{*}{$\begin{array}{l}\text { Initial size } \\
\times \text { treatment }\end{array}$} \\
\hline & & & & & & Intercept & Initial size & Treatment & \\
\hline \multirow[t]{16}{*}{ Diameter } & A. pseudoplatanus & 04-07 & 1 & 1668 & 0.53 & 051 & 0.75 & -0.032 n.s. & -0.68 \\
\hline & & 04-05 & 2 & 1806 & 0.20 & 0.85 & 0.14 & -0.046 n.s. & -0.13 \\
\hline & & $05-06$ & 2 & 1712 & 0.41 & 0.42 & 0.46 & 0.46 n.s. & -0.47 \\
\hline & & 06-07 & 2 & 1668 & 0.54 & 0.59 & 0.42 & 0.18 & -0.41 \\
\hline & A. platanoides & 04-07 & 1 & 280 & 0.36 & 0.97 & 0.61 & -0.13 n.s. & -0.56 \\
\hline & & $04-05$ & 2 & 292 & 0.24 & 1.01 & 0.14 & -0.10 & -0.17 \\
\hline & & $05-06$ & 2 & 287 & 0.20 & 0.43 & 0.53 & 0.56 & -0.55 \\
\hline & & 06-07 & 2 & 280 & 0.47 & 0.64 & 0.46 & 0.18 & -0.44 \\
\hline & A. campestre & 04-07 & 1 & 586 & 0.33 & 0.93 & 0.31 & -0.21 & -0.42 \\
\hline & & 04-05 & 2 & 641 & 0.14 & 0.96 & 0.034 n.s. & -0.096 & 0.071 \\
\hline & & $05-06$ & 2 & 596 & 0.09 & 0.66 & 0.24 & 0.29 & -0.32 \\
\hline & & 06-07 & 2 & 586 & 0.39 & 0.91 & 0.16 & -0.12 & -0.17 \\
\hline & F. sylvatica & 04-07 & 1 & 215 & 0.78 & 1.29 & 0.50 & -0.88 & -0.11 n.s. \\
\hline & & $04-05$ & 2 & 223 & 0.55 & 1.03 & 0.18 & -0.28 & -0.072 n.s. \\
\hline & & $05-06$ & 2 & 216 & 0.52 & 0.72 & 0.36 & 0.10 n.s. & -0.28 \\
\hline & & 06-07 & 2 & 215 & 0.64 & 0.55 & 0.49 & 0.064 n.s. & -0.30 \\
\hline \multirow[t]{16}{*}{ Height } & A. pseudoplatanus & 04-07 & 37 & 1668 & 0.44 & 2.89 & 0.38 & 0.63 & -0.32 \\
\hline & & 04-05 & 51 & 1806 & 0.01 & 3.93 & 0.0097 & -0.024 n.s. & 0.0028 n.s. \\
\hline & & $05-06$ & 40 & 1712 & 0.20 & 3.43 & 0.13 & 0.28 & -0.13 \\
\hline & & 06-07 & 37 & 1668 & 0.62 & 2.68 & 0.37 & 0.86 & -0.34 \\
\hline & A. platanoides & 04-07 & 37 & 280 & 0.670 & 2.58 & 0.64 & 1.07 & -0.59 \\
\hline & & 04-05 & 51 & 292 & 0.45 & 3.70 & 0.12 & 0.25 & -0.13 \\
\hline & & $05-06$ & 40 & 287 & 0.70 & 2.99 & 0.34 & 0.70 & -0.32 \\
\hline & & 06-07 & 37 & 280 & 0.78 & 2.71 & 0.40 & 0.78 & -0.32 \\
\hline & A. campestre & 04-07 & 37 & 586 & 0.34 & 3.33 & 0.26 & 0.33 & -0.22 \\
\hline & & 04-05 & 51 & 641 & 0.04 & 4.04 & -0.038 & -0.11 & 0.043 \\
\hline & & $05-06$ & 40 & 596 & 0.27 & 3.47 & 0.14 & 0.24 & -0.13 \\
\hline & & 06-07 & 37 & 586 & 0.57 & 3.06 & 0.27 & 0.49 & -0.22 \\
\hline & F. sylvatica & 04-07 & 37 & 215 & 0.21 & 4.15 & 0.047 n.s. & -0.57 n.s. & 0.017 n.s. \\
\hline & & 04-05 & 51 & 223 & 0.01 & 4.01 & -0.016 n.s. & -0.28 n.s. & 0.073 n.s. \\
\hline & & $05-06$ & 40 & 216 & 0.30 & 3.72 & 0.064 & -0.064 n.s. & -0.029 n.s. \\
\hline & & 06-07 & 37 & 215 & 0.53 & 3.57 & 0.13 & -0.027 n.s. & -0.090 n.s. \\
\hline
\end{tabular}

Tested model $\log ($ growth $+k)=\log ($ initialsize $)+$ treat $+\log ($ initialsize $) \cdot$ treat where growth refers to diameter or height growth over the growth period, initial size to diameter or height at the beginning of the growth period, treat to treatment (treat $=0$ for $\mathrm{G}$ and treat $=1$ for $\mathrm{C}$ ). All models presented are statistically significant $(p<0.05)$. All coefficient estimates presented are significantly different from $0(p<0.05)$, unless otherwise specified (n.s.).

dominated by $F$. sylvatica and $A$. pseudoplatanus, suggesting a possible causal relationship. Similarly, Beaudet et al. (2007) suggested that in the case of two other shade tolerant species (Fagus grandifolia and Acer saccharum), when the canopy is opened, competition for light in gaps tends to maintain or reinforce a pre-existing hierarchy between species instead of reversing it, especially when interspecific differences in postdisturbance growth are small.

At the end of the three years, seedlings of $A$. platanoides and $A$. campestre were still present in the seedling bank and displayed the same vitality than the other species, as suggested by large height and diameter increments. The filter against A. platanoides and A. campestre is therefore expected to occur during the next steps of the regeneration process, most probably in relation to increasing competition among seedlings. Intra- and interspecific competition among tree seedlings did not play a significant role during the acclimation period. However, since seedling density was high, competition among seedlings is expected to become more intense during the following years as the seedlings grow and preempt more available 

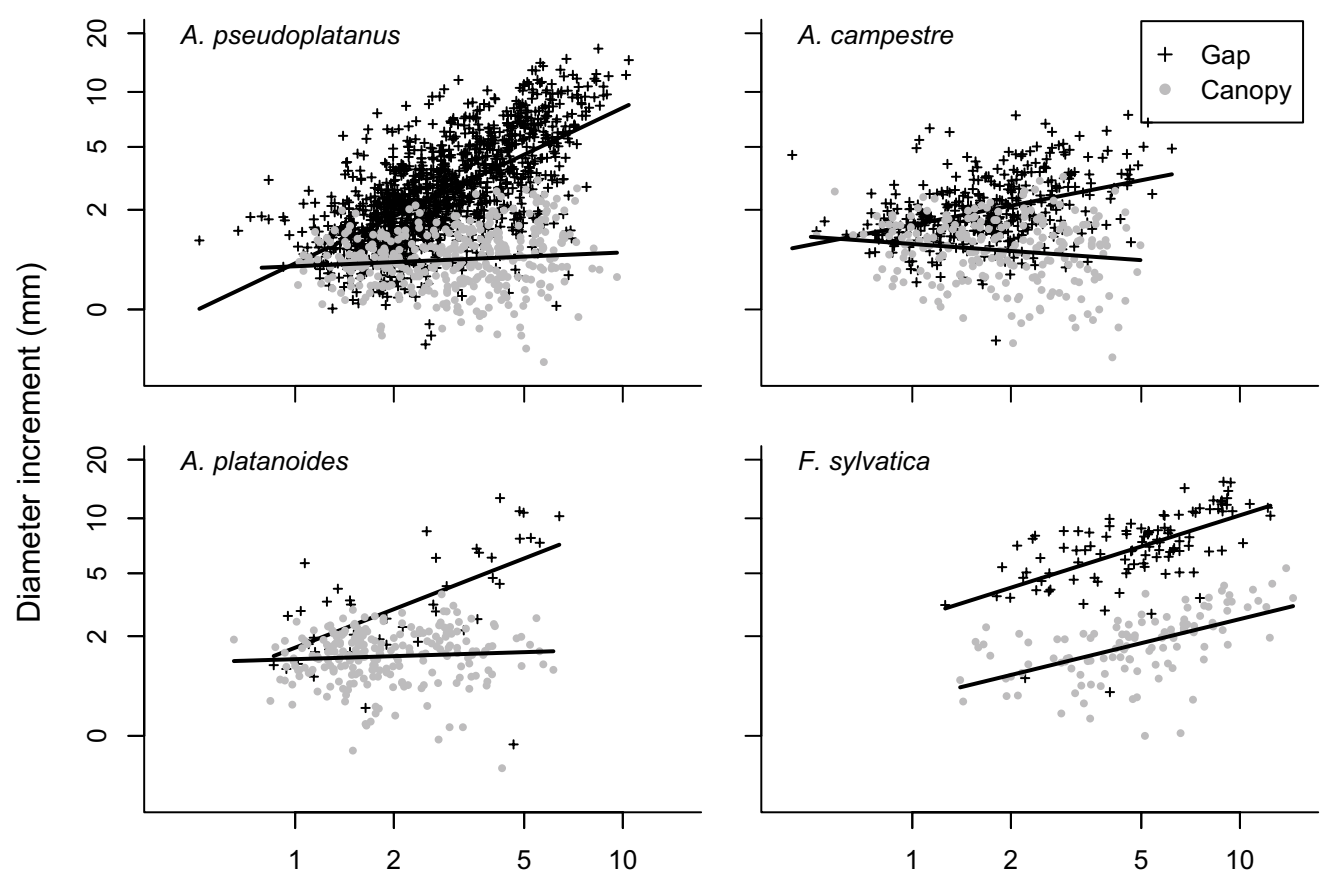

Initial diameter $(\mathrm{mm})$

Figure 3. Relationships between initial diameter (D04, measured in 2004) and diameter increment over the whole growth period (D07-D04) for Canopy and Gap seedlings of the four species. Data are represented on a log-log scale.

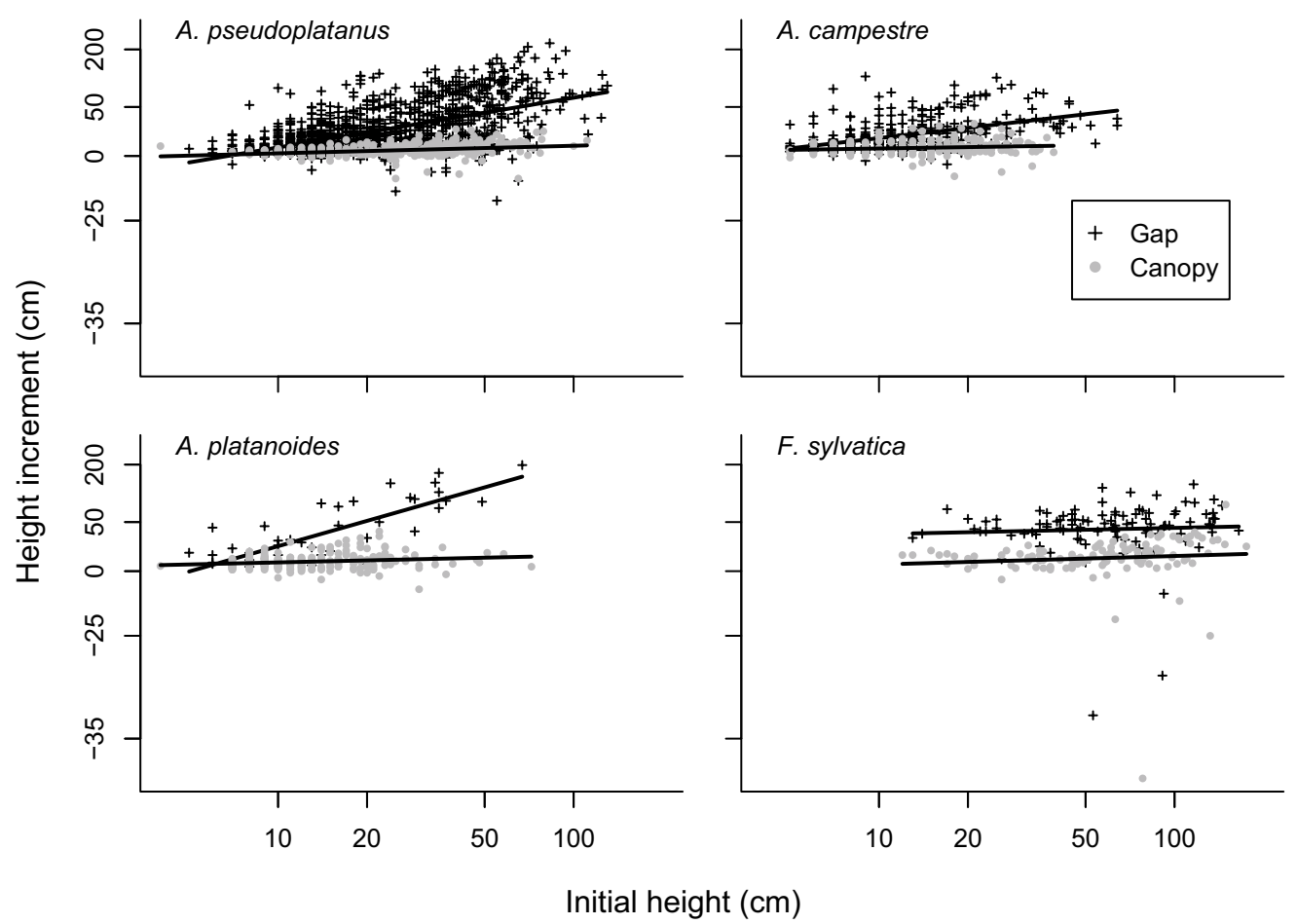

Figure 4. Relationships between initial height (H04, measured in 2004) and height increment over the whole growth period (H07-H04) for Canopy and Gap seedlings of the four species. Data are represented on a log-log scale. 

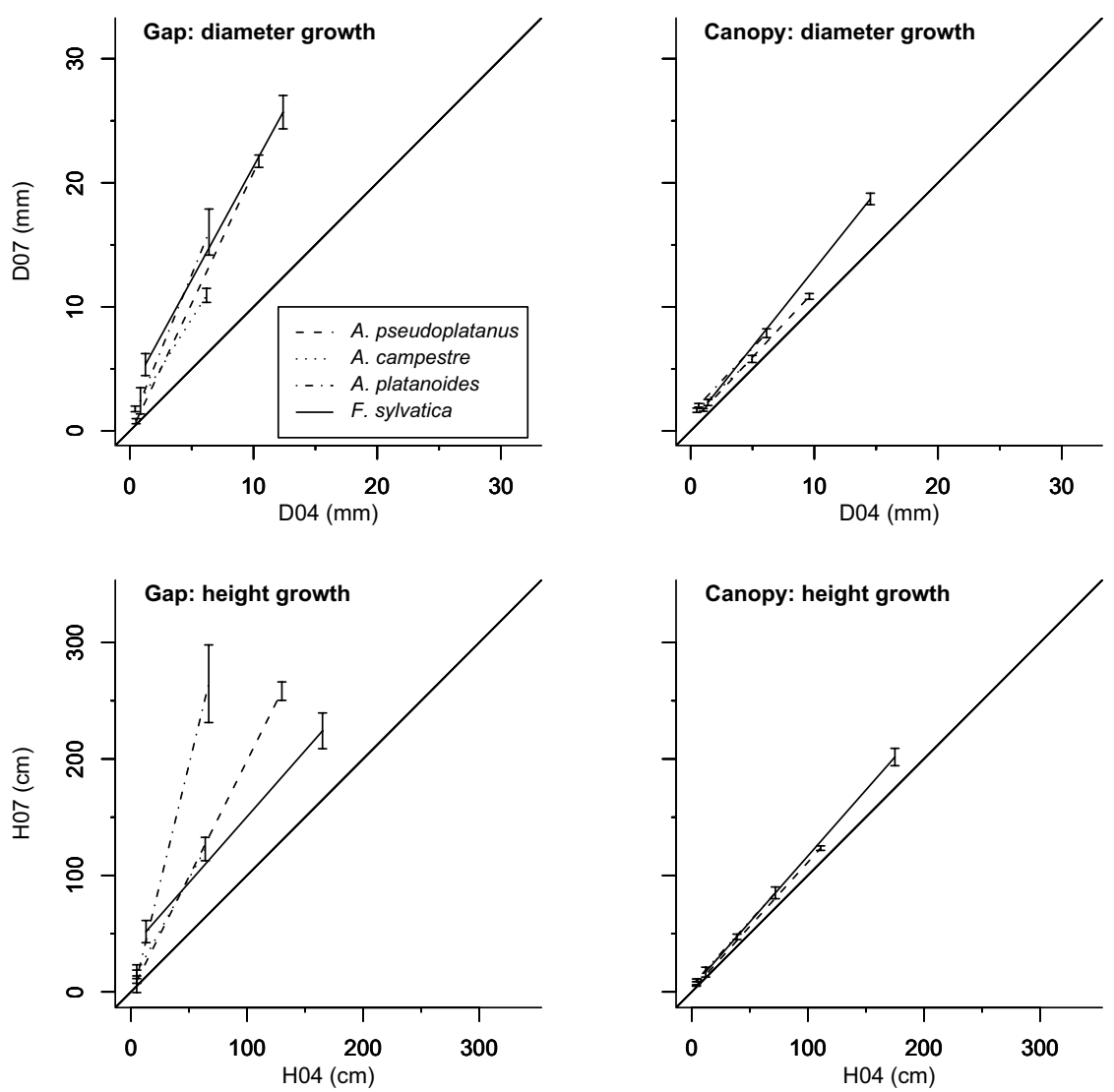

Figure 5. Relationship between initial diameter or height (D04, H04) and diameter or height reached three years after canopy opening (D07, H07) for canopy and gap seedlings, for each of the four species. Vertical bars represent the pointwise $95 \%$ confidence interval for the predictor.

resources. Under the irradiance levels prevailing at the study site $(R I<50 \%)$, F. sylvatica seedlings are known to be very competitive towards other species (Stancioiu and O'Hara, 2006). Data about the competitivity of the three Acer species at these stages would be needed to estimate the effect of interseedling competition on the survival and growth of the four species, but are still lacking.

Irrespective of the effective competitive ability of $A$. platanoides and A. campestre seedlings towards other tree species, their small size constituted a major disadvantage, compared to $F$. sylvatica and A. pseudoplatanus seedlings (Bohn and Nyland, 2003). This handicap already existed at the beginning of the study when the gaps were created and increased during the three years after gap opening, even in the absence of significant competition among seedlings, as a result of the positive relationship between seedling growth and size. In addition, this disadvantage should become more pronounced with the probable onset of a significant inter-seedling competition (Ammer et al., 2008) and should eventually lead to the death of $A$. platanoides and $A$. campestre seedlings.

\subsection{Dynamics of the persistent seedling bank}

Since seedling size before canopy opening was the main factor explaining post-release growth and is probably also a major determinant of long-term seedling dominance, questions arise as to the formation of the seedling bank under closed canopy and the development of size hierarchies within the seedling bank.

Coppice-with-standards are characterised by regular and frequent thinnings that create suitable conditions for lightdemanding species (Van Calster et al., 2008). Until the 1960 's, the study forest was managed according to these principles and many light-demanding species could establish. It was then converted into high forest and, as of that date, only a few low-intensity thinnings were performed, creating small canopy gaps that rapidly closed again. The seedling bank observed at the beginning of the experiment in the undisturbed stand had established under such a canopy disturbance regime. These regimes, where intermediate and transient canopy disturbance events prevail, are typical of F. sylvatica-dominated high forests of central and western Europe (Nagel and Diaci, 2006). These perturbation regimes were recognised as favouring shade-tolerant species that form advance regeneration under closed canopy and that are able to take advantage of small ephemeral canopy openings (Webster and Lorimer, 2005), where successful trees often undergo multiple suppression-and-release episodes prior to reaching the upper canopy (Canham, 1988; Wright et al., 2000). F. sylvatica has been described as having a stop-and-grow behaviour (Hahn, 2007), therefore making it well adapted to canopy 
opening regimes where small gaps are created. Similar data are not available for the three Acer species at this time.

In the present experiment, low mortality and continuous height and radial growth under closed canopy conditions were observed for all four species, supporting previous studies that reported a high shade tolerance for $F$. sylvatica (Madsen and Hahn, 2008; Stancioiu and O'Hara, 2006), A. pseudoplatanus (Hein et al., 2009; Petritan et al., 2009), A. platanoides (Webster et al., 2005) and A. campestre (Modry et al., 2004). Under a closed canopy, the four species had very similar growth-size relationships, showing that the differences observed in their social status within the persistent seedling bank do not originate from interspecific differences in height or diameter growth under low light conditions. Many studies have suggested that the differences observed in the social status of the four species may have originated in inter-specific differences in survival rates under closed canopy (Tanaka et al., 2008) and, more specifically, in differences in the relationship between survival rate and seedling size. This relationship may strongly vary among species, leading to interspecific differences in maximum seedling height observed under low light conditions (Kubota et al., 1994; Messier et al., 1999). However, the present study did not allow to accurately estimate seedling mortality rates because of the short duration of the study and the small size of selected regeneration patches with respect to the high temporal and spatial stochasticity of mortality occurrence.

\subsection{Implications for forest management}

Former coppice-with-standards growing on limestone sites in Western Europe are usually characterised by a highly diversified overstorey. These stands typically include a mixture of shade-tolerant, intermediate and intolerant species, and the species diversity may be difficult to maintain when regenerating the stand using traditional silvicultural methods. Several studies have shown the difficulty of sustaining the future of some particular species in these stands despite their presence in the canopy and have highlighted the need for adapted regeneration methods (Butler Manning, 2007; Van Calster et al., 2008). An earlier study (Collet et al., 2008) showed that in situations where advance regeneration is well established, methods based on the creation of gaps of different sizes may not lead to a higher species diversity and suggested that additional silvicultural treatments would be needed to obtain a more diverse regeneration. Otherwise, the high diversity existing in the mature stand might be lost in a single generation.

The present study focused on the recruitment of advance seedlings persisting under a closed canopy ( $F$. sylvatica, A. pseudoplatanus, A. platanoides and A. campestre) and showed that the period of acclimation to sudden exposure to open canopy conditions was not a limiting step in the recruitment process of the seedlings. These observations imply that silvicultural treatments using more gradual canopy opening in order to alleviate post-release shock as proposed by Messier et al. (1999) or by Krazowski and Wang (2003) would not help in maintaining existing species diversity in this type of stands.
On the contrary, all four species respond positively to canopy opening, and subsequent competition with other tree species is most probably the process that limits the recruitment of A. platanoides and $A$. campestre, suggesting that tending treatments controlling the development of the competing advance $F$. sylvatica and $A$. pseudoplatanus seedlings before or immediately after canopy opening should be recommended in order to enhance $A$. platanoides and A. campestre recruitment.

Acknowledgements: We thank Philippe Balandier and Franck Sterck for their helpful comments on an early draft of the manuscript. We are very grateful to Bruno Garnier, Michel Pitsch and Léon Wehrlen for their technical assistance during field work. Funding was provided by Region Lorraine (project "Jeune Equipe 2005", and grant 342.2004 to BC), Office National des Forêts ("ModelFor" project) and INRA (project "Forêts mélangées" from the ECOGer programme, and grant BTH01667 to BC).

\section{REFERENCES}

Ammer C., Stimm B., and Mosandl R., 2008. Ontogenetic variation in the relative influence of light and belowground resources on European beech seedling growth. Tree Physiol. 28: 721-728.

Aussenac G., 2000. Interactions between forest stands and microclimate: ecophysiological aspects and consequences for sylviculture. Ann. For. Sci. 57: 287-301.

Balandier P., Collet C., Miller J.H., Reynolds P.E., and Zedaker S.M., 2006. Designing forest vegetation management strategies based on the mechanisms and dynamics of crop tree competition by neighboring vegetation. Forestry 79: 3-27.

Beaudet M., Brisson J., Gravel D., and Messier C., 2007. Effect of a major canopy disturbance on the coexistence of Acer saccharum and Fagus grandifolia in the understorey of an old-growth forest. J. Ecol. 95: 458-467.

Bohn K.K. and Nyland R.D., 2003. Forecasting development of understory American beech after partial cutting in uneven-aged northern hardwood stands. For. Ecol. Manage. 180: 453-461.

Bourgeois L., Messier C., and Brais S., 2004. Mountain maple and balsam fir early response to partial and clear-cut harvesting under aspen stands of northern Quebec. Can. J. For. Res. 34: 2049-2059.

Brunner A., 1998. A light model for spatially explicit forest stand models. For. Ecol. Manage. 107: 19-46.

Butler Manning B., 2007. Stand structure, gap dynamics and regeneration of a semi-natural mixed beech forest on limestone in central Europea case study, Ph.D. thesis, Albert-Ludwigs-Universität, Freiburg im Bresgau, Germany, p. 253.

Canham C.D., 1988. Growth and canopy architecture of shade-tolerant trees: response to canopy gaps. Ecology 69: 786-795.

Caquet B., 2008. Réactions de semis naturels de hêtre (Fagus sylvatica L.) et d'érable sycomore (Acer pseudoplatanus L.) à l'ouverture du couvert : croissance et ajustements fonctionnels, Ph.D. thesis, Université Henri Poincaré, Nancy, France.

Chesson P., Pacala S.W., and Neuhauser C., 2001. Environmental niches and ecosystem functioning. In: Kinzing A.P., Pacala S., and Tilman G.D. (Eds.), The functional consequences of biodiversity, Princeton University Press, Princeton, NJ, pp. 213-245.

Clark J.S., Beckage B., Camill P., Cleveland B., Hille Ris Lambers J., Lichter J., McLachlan J., Mohan J., and Wyckoff P.H., 1999. Interpreting recruitment limitation in forests. Am. J. Bot. 86: 1-16.

Collet C. and Chenost C., 2006. Using competition and light estimates to predict diameter and height growth of naturally regenerated beech seedlings growing under changing canopy conditions. Forestry 79: 489-502. 
Collet C., Piboule A., Leroy O., and Frochot H., 2008. Advance Fagus sylvatica and Acer pseudoplatanus seedlings dominate tree regeneration in a mixed broadleaved former coppice-with-standards forest. Forestry 81: 135-150.

Dalling J.W., Hubbell S.P., and Silvera K., 1998. Seed dispersal, seedling establishment and gap partitioning among tropical pioneer trees. J. Ecol. 86: 674-689.

Decocq G., Aubert M., Dupont F., Bardat J., Wattez-Franger A., Saguez R., De Foucault B., Alard D., and Delelis-Dusollier A., 2005. Silviculture-driven vegetation change in a European temperate deciduous forest. Ann. For. Sci. 62: 313-323.

Gonzalez M., Deconchat M., Balent G., and Cabanettes A., 2008. Diversity of woody plant seedling banks under closed canopy in fragmented coppice forests. Ann. For. Sci. 65: 511.

Grogan J., Landis R.M., Ashton M.S., and Galvao J., 2005. Growth response by big-leaf mahogany (Swietenia macrophylla) advance seedling regeneration to overhead canopy release in southeast Para, Brazil. For. Ecol. Manage. 204: 399-412.

Grubb P.J., 1977. The maintenance of species richness in plant communities: the importance of the regeneration niche. Biol. Rev. 52: 107145 .

Hahn K., 2007. From degradation to regeneration! Studies of dead wood, gaps, flora, and regeneration in beech-dominated (Fagus sylvatica L.) forests and the application for nature-based forest management, Ph.D. thesis, Copenhagen University, Copenhagen, Denmark.

Hein S., Collet C., Ammer C., Le Goff N., Skovsgaard J.P., and Savill P.S., 2009. A review of growth and stand dynamics of Acer pseudoplatanus L. in Europe: implications for silviculture. Forestry: 82: 361-385.

Kelly C.K. and Bowler M.G., 2002. Coexistence and relative abundance in forest trees. Nature 417: 437-440.

Kneeshaw D., Williams H., Nikinmaa E., and Messier C., 2002. Patterns of above- and below-ground response of understory conifer release 6 years after partial cutting. Can. J. For. Res. 32: 255-265.

Krasowski M.J. and Wang J.R., 2003. Aboveground growth reponses of understory Abies lasiocarpa saplings to different release cuts. Can. J. For. Res. 33: 1593-1601.

Kubota Y., Konno Y., and Hiura T., 1994. Stand structure and growth patterns of understorey trees in a coniferous forest, Taisetsuzan National Park. Northern Japan Ecological Research 9: 333-341.

Madsen P. and Hahn K., 2008. Natural regeneration in a beech-dominated forest managed by close-to-nature principles. A gap cutting based experiment. Can. J. For. Res. 38: 1716-1729.

Messier C., Doucet R., Ruel J.C., Claveau Y., Kelly C., and Lechowicz M.J., 1999. Functional ecology of advance regeneration in relation to light in boreal forests. Can. J. For. Res. 29: 812-823.

Modry M., Hubeny D., and Rejsek K., 2004. Differential response of naturally regenerated European shade tolerant tree species to soil type and light availability. For. Ecol. Manage. 188: 185-195.

Nagel T.A. and Diaci J., 2006. Intermediate wind disturbance in an oldgrowth beech-fir forest in southeastern Slovenia. Can. J. For. Res. 36: 629-638.

Nakashizuka T., 2001. Species coexistence in temperate, mixed deciduous forests. Trends Ecol. Evol. 16: 205-210.
Örlander G. and Karlsson C., 2000. Influence of shelterwood density on survival and height increment of Picea abies advance growth. Scand. J. For. Res. 10: 20-29.

Parish R. and Antos J.A., 2005. Advanced regeneration and seedling establishment in small cutblocks in high-elevation spruce-fir forest at Sicamous Creek, southern British Columbia. Can. J. For. Res. 35: $1877-1888$.

Pearson T.R.H., Burslem F.R.P., Goeriz R.E., and Dalling J.W., 2003. Regeneration niche partitioning in neotropical pioneers: effects of gap size, seasonal drought and herbivory on growth and survival. Oecologia 137: 456-465.

Peet R.K. and Christensen N.L., 1987. Competition and tree death. Bioscience 7: 586-595.

Petritan A.M., von Lüpke B., and Petritan I.C., 2009. Influence of light availability on growth, leaf morphology and plant architecture of beech (Fagus sylvatica L.), maple (Acer pseudoplatanus L.) and ash (Fraxinus excelsior L.) saplings. Eur. J. For. Res. 128: 61-74.

Piboule A., Collet C., Frochot H., and Dhôte J.F., 2005. Reconstructing crown shape from stem diameter and tree position to supply light models. I. Algorithms and comparison of light simulations. Ann. For. Sci. 62: 645-657.

Puettmann K.J. and Ammer C., 2007. Trends in North American and European regeneration research under the ecosystem management paradigm. Eur. J. For. Res. 126: 1-9.

R Development Core Team, 2007. R: A language and environment for statistical computing, R Foundation for Statistical Computing, Vienna, Austria.

Silander J.A. and Pacala S.W., 1985. Neighborhood predictors of plant performance. Oecologia 66: 256-263.

Silvertown J., 2004. Plant coexistence and the niche. Trends Ecol. Evol. 19: 605-611.

Stancioiu P.T. and O'Hara K.L., 2006. Regeneration growth in different light environments of mixed species, multiaged, mountainous forests of Romania. Eur. J. For. Res. 125: 151-162.

Takenaka A., 2006. Dynamics of seedling populations and tree species coexistence in a forest: a simulation study. Ecol. Res. 21: 356-363.

Tanaka H., Shibata M., Masaki T., Iida S., Niiyama K., Abe S., Kominami Y., and Nakashizuka T., 2008. Comparative demography of three coexisting Acer species in gaps and under closed canopy. J. Veg. Sci. 19(1): 127-U127.

Van Calster H., Baeten L., Verheyen K., De Keersmaeker L., Dekeyser S., Rogister J.E., and Hermy M., 2008. Diverging effects of overstorey conversion scenarios on the understorey vegetation in a former coppice-with-standards forest. For. Ecol. Manage. 256: 519-528.

Webster C.R. and Lorimer C.G., 2005. Minimum opening sizes for canopy recruitment of midtolerant tree species: a retrospective approach. Ecol. Appl. 15: 1245-1262.

Webster C.R., Nelson K., and Wangen S.R., 2005. Stand dynamics of an insular population of an invasive tree, Acer platanoides. For. Ecol. Manage. 208(1-3): 85-99.

Wright E.F., Canham C.D., and Coates K.D., 2000. Effects of suppression and release on sapling growth for 11 tree species of northern, interior British Columbia. Can. J. For. Res. 30: 1571-1580. 